DOI: $10.29303 / \mathrm{jrpb} . v 9 \mathrm{i} 2.240$

ISSN 2301-8119, e-ISSN 2443-1354

Tersedia online di http://jrpb.unram.ac.id/

\title{
ANALISIS ERGONOMI DAN ANALISIS EKONOMI MESIN PENCUCI UBI
}

\author{
Ergonomic and Engineering Economic Analysis on Sweet Potato Washing Machines
}

\section{Wahyu K Sugandi*), Asep Yusuf, Surya P Sukoco}

Departemen Teknik Pertanian dan Biosistem, Fakultas Teknologi Industri Pertanian, Universitas Padjadjaran, Jl. Raya Bandung Sumedang Km 21 Jatinangor, Indonesia

\author{
Email $^{*}$ : wahyu.sugandi@unpad.ac.id
}

Diterima: Juli 2021

Disetujui: September 2021

\begin{abstract}
Handling of post-harvest sweet potatoes is necessary to maintain the quality of Sweet Potatoes. Handling includes washing, sorting, storage, packaging, shipping, and marketing. This study aims to analyze ergonomics and economic feasibility of sweet potato washing machines. The research method used was descriptive analysis by measuring and calculating the sweet potato washing machine, in order to provide information on the assessment of ergonomics and economic feasibility. The results of ergonomic analysis for adjusting anthropometric data indicate the difference between shoulder height and machine height and shoulder width with a width of $35.24 \mathrm{~cm}$ and $3.86 \mathrm{~cm}$ respectively. The evaluation of work posture using OWAS define that there are 2 work postures included in category 3 . Therefore, improvement is necessary; biomechanical analysis of NIOSH produces LI value <1 for all load weights lifted by the operator except when the operator lifted the water. The noise and vibration levels of most engines at no-load conditions were $88.92 \mathrm{~dB}$ and $11.056 \mathrm{~m} / \mathrm{s}^{2}$ respectively, while those with loads were $77 \mathrm{~dB}$ and $21.87 \mathrm{~m} / \mathrm{s}^{2}$ respectively. The results of the economic analysis showed that the sweet potato washing machine produced an NPV value of Rp 39,842,284.52, BC Ratio of 1.466, IRR of 8.5\% and PBP of investment would benefit in the first year. Then BEP will be achieved after producing $14,956 \mathrm{~kg}$.
\end{abstract}

Keywords: economic analysis; ergonomics analysis; sweet potato washing machine

\begin{abstract}
ABSTRAK
Penanganan pascapanen ubi jalar dilakukan untuk mempertahankan kualitas Ubi Jalar tersebut. Penanganannya meliputi: pencucian, sortasi, penyimpanan, pengemasan dan pengangkutan, serta pemasaran hasil. Penelitian ini bertujuan menganalisis ergonomi dan kelayakan ekonomi dari mesin pencuci ubi. Metode penelitian yang digunakan adalah analisis deskriptif dengan melakukan pengukuran dan perhitungan terhadap mesin pencuci ubi, sehingga memberikan informasi mengenai penilaian ergonomi dan kelayakan ekonomi. Hasil analisis ergonomi untuk penyesuaian data antropometri menunjukkan adanya selisih antara tinggi bahu dengan tinggi mesin dan lebar bahu dengan lebar mesin masing-masing sebesar $35,24 \mathrm{~cm}$ dan $3,86 \mathrm{~cm}$. Kemudian dari hasil evaluasi postur kerja menggunakan OWAS terdapat 2 postur kerja yang termasuk ke dalam kategori 3, sehingga perlu ada perbaikan;
\end{abstract}


analisis biomekanika NIOSH menghasilkan nilai LI $<1$ untuk semua berat beban yang diangkat operator kecuali saat operator mengangkat air. Tingkat kebisingan dan getaran dari mesin pencuci ubi pada kondisi tanpa beban masing-masing sebesar 88,92 dB dan 11,056 $\mathrm{m} / \mathrm{s}^{2}$, sedangkan pada kondisi dengan beban masing-masing $77 \mathrm{~dB}$ dan $21,87 \mathrm{~m} / \mathrm{s}^{2}$. Hasil analisis ekonomi menunjukkan mesin pencuci ubi dengan menghasilkan nilai NPV Rp 39.842.284,52, BC Ratio sebesar 1,466, IRR sebesar 8,5\%, dan PBP investasi akan mendapatkan keuntungan pada tahun pertama. Kemudian BEP akan tercapai setelah memproduksi $14.956 \mathrm{~kg}$.

Kata kunci: analisis ekonomi; analisis ergonomika; mesin pencuci ubi

\section{PENDAHULUAN}

\section{Latar Belakang}

Pangan merupakan kebutuhan pokok manusia. Melalui penataan pola makan yang tidak tergantung pada satu sumber pangan, memungkinkan masyarakat dapat menetapkan pangan pilihan sendiri, membangkitkan ketahanan pangan keluarga masing-masing, yang berujung pada peningkatan ketahanan pangan nasional. Penganekaragaman pangan (diversifikasi pangan) merupakan jalan keluar yang saat ini dianggap paling rasional untuk memecahkan masalah pemenuhan kebutuhan pangan (khususnya sumber karbohidrat).

Ubi jalar merupakan salah satu jenis pangan yang berfungsi sebagai sumber karbohidrat. Ubi jalar bisa menjadi salah satu alternatif untuk mendampingi beras menuju ketahanan pangan.

Penanganan pascapanen ubi jalar dilakukan untuk mempertahankan kualitas ubi jalar tersebut. Penanganannya meliputi: pencucian, sortasi, penyimpanan, pengemasan dan pengangkutan, serta pemasaran hasil (Rukmana, 1997). Proses pencucian pada penanganan pasca panen Ubi Cilembu menjadi hal yang penting karena tingkat kebersihan ubi menjadi salah satu faktor penentu kualitas produk (Suprapti, 2003). Akan tetapi, saat ini proses pencucian ubi sebagian besar dilakukan secara manual. Hal ini tentunya kurang efektif karena membutuhkan tenaga dan memakan waktu yang lama.

Proses pencucian ubi yang dilakukan dengan membersihkan ubi menggunakan kompresor dengan tekanan tinggi berdampak pada terkelupasnya kulit ubi. Padahal yang diharapkan hanya kotoran tanahnya saja yang bisa dibersihkan. Tentunya hal ini akan menurunkan kualitias dari ubi itu sendiri.

Laboratorium Alat dan Mesin Pertanian, Bengkel Logam Kayu dan Rotan, FTIP, Universitas Padjadjaran telah melakukan rancang bangun mesin pencuci ubi. Penggunaan mesin pencuci ubi ini diharapkan dapat meningkatkan efisiensi dan efektifitas waktu dalam pencucian ubi serta dapat menghasilkan ubi yang lebih higienis dan tidak menyebabkan kecacatan fisik.

Namun, pada mesin pencuci ubi tersebut perlu dilakukan analisis teknis untuk mengetahui kelayakan ergonominya yang lebih efisien dan efektif daripada pencucian menggunakan kompresor. sehingga keluhan sakit pada pergelangan tangan dapat diatasi. Selain itu, kelayakan ekonomi mesin ini perlu dievaluasi untuk menilai apakah penggunaan mesin secara ekonomis menguntungkan bagi para penggunanya.

\section{Tujuan}

Penelitian ini bertujuan menganalisis ergonomi dan kelayakan ekonomi dari mesin pencuci ubi.

\section{METODOLOGI PENELITIAN}

\author{
Alat dan Bahan \\ Alat yang digunakan pada penelitian \\ ini adalah mesin pencuci ubi, meteran, \\ penggaris, sound level meter, stopwatch,
}


timbangan, vibration meter, Software Ergofellow, laptop. Bahan yang digunakan adalah Ubi Cilembu sebanyak $30 \mathrm{~kg}$

\section{Tempat Penelitian}

Salah satu pertanian ubi jalar berada di desa Cilembu, Kecamatan Pamulihan, Kabupaten Sumedang, Jawa Barat. Ubi jalar di desa cilembu memiliki lahan tanam sebesar 137,9 hektar dengan produksi sebesar 7 ton/ha/tahun (Data Statistik, kantor desa Cilembu). Produksi ubi jalar yang cukup besar di desa Cilembu tersebut, sering kali dijadikan peluang untuk para petani di desa Cilembu mengekspor ubi jalar ke luar negeri.

Rata-rata pertumbuhan volume ekspor ubi jalar di desa Cilembu meningkat sebesar $91,47 \%$ per tahun, demikian halnya dengan nilai ekspornya yang meningkat sebesar $108,35 \%$ per tahun. Peningkatan volume ekspor ubi jalar cukup drastis terjadi tahun 2004 yaitu sebesar 124,83\% atau ekspor ubi Jalar mencapai 11,82 juta ton (Suwandi, 2016). Akan tetapi, untuk bisa lolos dalam tahap seleksi kualitas ubi jalar yang dapat diekspor, penangan pasca panen terhadap ubi jalar tersebut perlu diperhatikan.

\section{Metode}

Metode penelitian yang digunakan dalam penelitian ini adalah analisis deskriptif, yaitu mengumpulkan data melalui pengukuran, pengamatan, wawancara serta melakukan perhitungan dan penilaian risiko posisi kerja. Kemudian data dianalisis sehingga diperoleh informasi mengenai kelayakan ergonomi dan ekonomi mesin pencuci ubi di Desa Cilembu, Kecamatan Pamulihan, Kabupaten Sumedang, Jawa Barat.

Dalam penelitian ini terdapat beberapa tahapan pengerjaan, penelitian ini dimulai dengan menyiapkan peralatan dan bahan yang akan digunakan dalam proses pencucian ubi menggunakan mesin pencuci ubi. Tahapan berikutnya adalah mengecek semua komponen mesin dan menyiapkan alat ukur yang akan digunakan. Setelah itu melakukan pengamatan pada proses pencucian ubi sehingga mengetahui komponen serta bagian mesin yang berhubungan dengan operator.

Tahapan berikutnya melakukan pengumpulan data untuk aspek ergonomi dari mesin, salah satunya mengukur dimensi dari mesin yang berhubungan dengan operator. Data pengukuran ini akan digunakan dalam penyesuaian dimensi mesin dengan data antropometri operator. Selanjutnya menghitung kebutuhan biaya produksi pada saat mesin beroperasi. Data perhitungan biaya produksi ini akan digunakan untuk menentukan analisis kelayakan ekonomi mesin pencuci ubi.

Tahapan terakhir melakukan analisis ergonomi dan analisis kelayakan ekonomi. Analisis ergonomi yang dilakukan meliputi antropometri, analisis OWAS (Ovako Working Posture Analysis System), analisis NIOSH (National Institute of Occupational Safety and Health), tingkat kebisingan dan getaran. Sedangkan analisis ekonomi teknik yang dilakukan meliputi penentuan NPV (Net Present Value), IRR (Internal Rate of Return), BC Ratio (Benefit Cost Ratio), BEP (Break Even Point) dan PBP (Pay Back Period).

\section{HASIL DAN PEMBAHASAN}

\section{Gambaran Umum Mesin Pencuci Ubi}

Mesin Pencuci Ubi Prototipe I yang dirancang bangun oleh Laboratorium Alat dan Mesin Pertanian Departemen Teknik Pertanian dan Biosistem Universitas Padjadjaran merupakan mesin pencuci Ubi Cilembu dengan metode basah (wet method) dan menghasilkan pusaran air dari silinder brush yang digerakkan menggunakan satu motor penggerak (Sugandi, et al., 2019). Mesin Pencuci Ubi Prototype I dapat dilihat pada Gambar 1.

Mesin Pencuci Ubi Prototipe I memiliki dimensi Diameter silinder 390 $\mathrm{mm}$, dan tinggi $330 \mathrm{~mm}$. Sedangkan dimensi rangka yaitu panjang $400 \mathrm{~mm}$, lebar $400 \mathrm{~mm}$, dan tinggi $550 \mathrm{~mm}$. Komponen utama mesin ini terdiri dari 
rangka, unit pembersih, sistem transmisi, saluran keluaran bahan, roda, tombol ONOFF, dan motor penggerak. Perancangan unit pembersih bertujuan untuk mempercepat proses pembersihan Ubi Cilembu setelah dipanen. Mesin ini bekerja menggunakan motor listrik 1,5 HP yang memiliki unit transmisi menggunakan sabuk dan puli motor penggerak dan diteruskan ke poros pembersih.

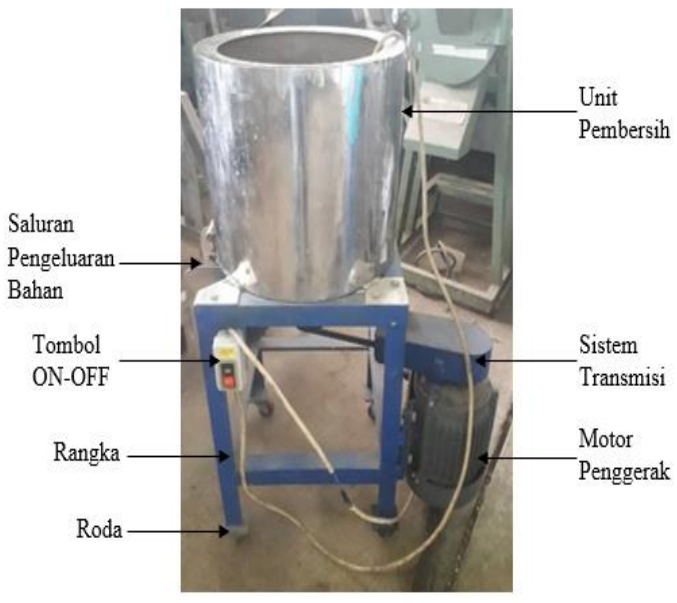

Gambar 1. Mesin Pencuci Ubi Prototipe I (Sumber: Sugandi, et al., 2019)

\section{Hasil Analisis Antropometri}

Analisis penyesuaian data antropometri dilakukan dengan cara mengukur dimensi tubuh operator (Nurmianto, 1996) yang nantinya akan dibandingkan dengan dimensi mesin pencuci ubi yang diteliti. Dimensi tubuh operator yang di gunakan yaitu tinggi bahu dan juga lebar bahu operator, dimana tinggi bahu operator berhubungan dengan tinggi mesin dan lebar bahu berhubungan dengan lebar mesin. Kedua parameter dimensi tubuh operator, kemudian dibandingkan dengan dimensi mesin.

Tinggi bahu rata-rata operator adalah sebesar $141 \mathrm{~cm}$ dan tinggi dari mesin pencuci Ubi Cilembu sendiri, yaitu $88 \mathrm{~cm}$, yang diukur dari mulai roda yang berada di bagian bawah mesin hingga bagian atas wadah pencucian. Dari hasil perbandingan ini, terdapat selisih antara tinggi mesin dengan data antropometri tinggi bahu sebesar $53 \mathrm{~cm}$. Hasil selisih ini menunjukkan bahwa ketinggian mesin pencuci Ubi Cilembu lebih rendah daripada data antropometri tinggi bahu. Dengan demikian seluruh operator dapat menggunakan mesin pencuci ubi tersebut dengan nyaman.

Lebar bahu rata-rata operator adalah sebesar 42,3 cm sementara lebar mesin pencuci Ubi Cilembu, yaitu $40 \mathrm{~cm}$. Hasil selisih ini menunjukkan bahwa lebar mesin pencuci Ubi Cilembu kurang sesuai dengan data antropometri lebar bahu. Untuk dapat menyesuaikan antara lebar mesin dengan rata-rata lebar bahu operator, dapat dilakukan perbaikan atau modifikasi mesin.

Analisis Metode OWAS (Ovako Working Posture Analysis System) Evaluasi Postur Kerja untuk Posisi Mengangkat Ubi Kotor

Posisi mengangkat ubi kotor merupakan posisi awal dalam mengoperasikan mesin pencuci Ubi Cilembu (Gambar 2), wadah ubi yang berisikan ubi kotor diangkat oleh operator. Banyaknya ubi kotor yang diangkat operator yaitu seberat $8 \mathrm{~kg}$. Berat ubi kotor ini mengikuti kapasitas dari wadah pencucian.

Penilaian untuk postur kerja operator saat mengangkat ubi kotor yaitu 1121-1 (Gambar 3). Angka 1 pada digit pertama menunjukkan sikap punggung tegak. Angka 1 pada digit kedua menunjukkan sikap kedua lengan berada di bawah bahu. Angka 2 pada digit ketiga menunjukkan sikap kaki berdiri bertumpu pada kedua kaki dengan tegak. Angka 1 pada digit keempat menunjukkan berat beban yang diangkat kurang dari $10 \mathrm{~kg}$ dan angka 1 pada digit terakhir menunjukkan hasil dari analisis sikap kerja OWAS masuk ke dalam kategori 1. Kategori ini menunjukkan bahwa pada sikap kerja ini tidak masalah pada sistem musculoskeletal. Jadi tidak perlu ada perbaikan. 


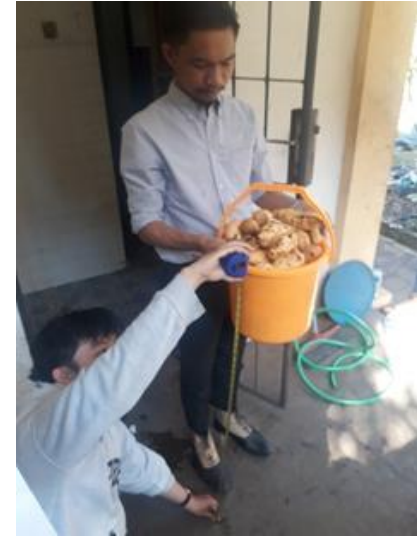

Gambar 2. Posisi Operator Mengangkat Ubi Kotor

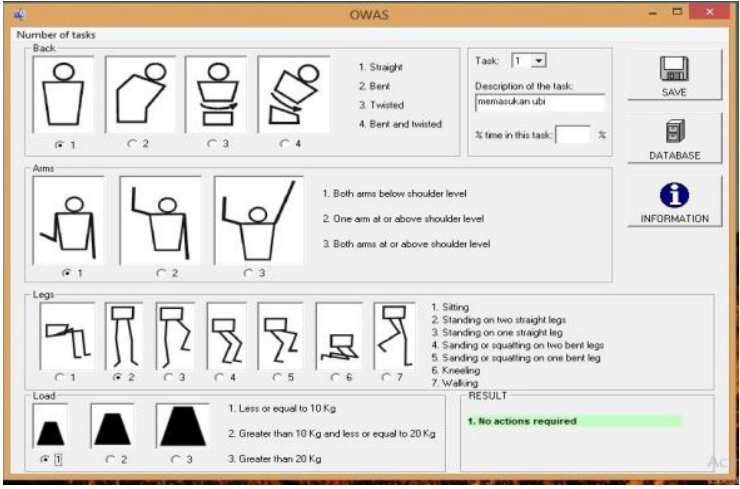

Gambar 3. Klasifikasi Sikap Kerja untuk Posisi Operator Mengangkat Ubi Kotor menggunakan Software Ergofellow 2.0

\section{Evaluasi Postur Kerja untuk Posisi Memasukkan Ubi Kotor}

Posisi kedua dari pengoperasian mesin pencuci Ubi Cilembu yaitu memasukkan ubi kotor ke dalam wadah pencucian (Gambar 4), operator memasukkan ubi kotor seberat $8 \mathrm{~kg}$ ke dalam wadah pencucian

Penilaian untuk postur kerja operator saat memasukkan ubi kotor ke wadah pencucian yaitu 1121-1 (Gambar 5). Angka 1 pada digit pertama menunjukkan sikap punggung lurus. Angka 1 pada digit kedua menunjukkan sikap kedua lengan berada di bawah bahu. Angka 2 pada digit ketiga menunjukkan sikap kaki berdiri bertumpu pada kedua kaki lurus. Angka 1 pada digit keempat menunjukkan berat beban yang diangkat kurang dari $10 \mathrm{~kg}$ dan angka 1 pada digit terakhir menunjukkan hasil dari analisis sikap kerja OWAS masuk ke dalam kategori 1. Kategori ini menunjukkan bahwa pada sikap kerja ini tidak masalah pada sistem musculoskeletal. Jadi tidak perlu ada perbaikan.

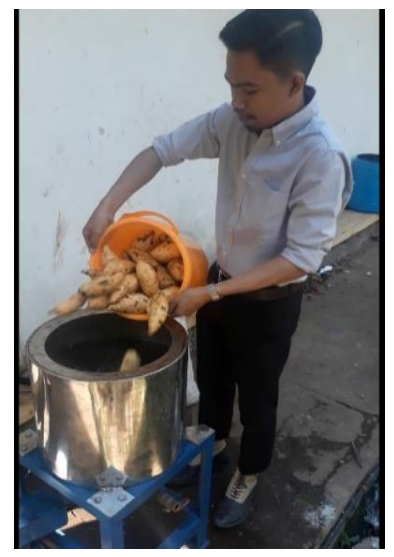

Gambar 4. Posisi Operator Memasukkan Ubi Cilembu Kotor

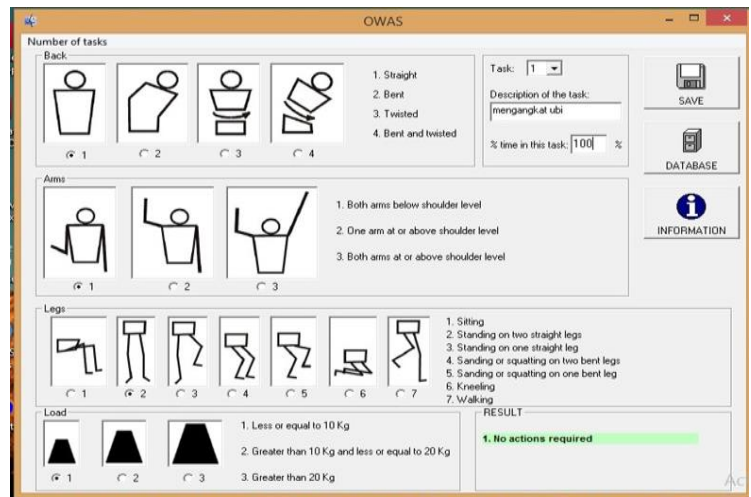

Gambar 5. Klasifikasi Sikap Kerja untuk Posisi Operator Memasukkan Ubi Kotor menggunakan Software Ergofellow 2.0

\section{Evaluasi Postur Kerja untuk Posisi Mengangkat Air}

Untuk mengoperasikan pencucian ubi perlu dilakukan pengisian air setelah ubi kotor dimasukan kedalam wadah pencucian (Gambar 6), wadah berisikan air diangkat oleh operator. Banyaknya air yang diangkat yaitu sebesar 10 liter.

Penilaian untuk postur kerja operator saat mengangkat air yaitu 2141-3 (Gambar 7). Angka 2 pada digit pertama menunjukkan sikap punggung membungkuk. Angka 1 pada digit kedua menunjukkan sikap kedua lengan berada di bawah bahu. Angka 4 pada digit ketiga menunjukkan sikap kaki berdiri bertumpu pada kedua kaki dengan lutut ditekuk. Angka 1 pada digit keempat menunjukkan 
berat beban yang diangkat kurang atau sama dengan $10 \mathrm{~kg}$ dan angka 3 pada digit terakhir menunjukkan hasil dari analisis sikap kerja OWAS masuk ke dalam kategori 3. Kategori ini menunjukkan bahwa pada sikap kerja ini berbahaya bagi sistem musculoskeletal (sikap kerja mengakibatkan pengaruh ketegangan yang signifikan). Perlu perbaikan segera mungkin.

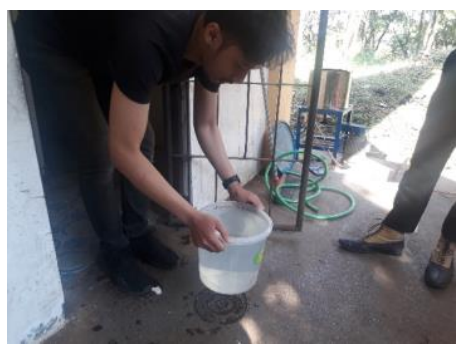

Gambar 6. Posisi Operator Mengangkat Air

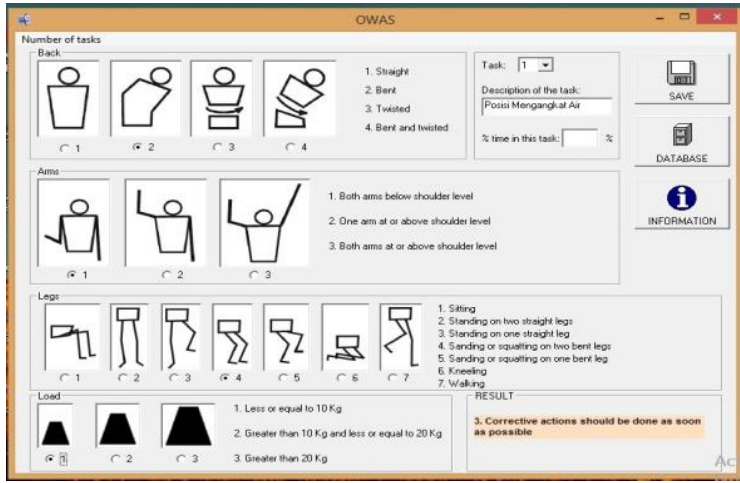

Gambar 7. Klasifikasi Sikap Kerja untuk

Posisi Operator Mengangkat Air menggunakan Software Ergofellow 2.0

Dari hasil analisis postur kerja operator saat mengangkat air masuk ke dalam kategori 3, yang berarti postur kerja ini perlu ada perbaikan segera mungkin. Perbaikan yang dapat dilakukan yaitu pengambilan air dapat dilakukan dari bak penampungan air yang tingginya kurang lebih setinggi pinggul rata-rata antropometri penduduk Indonesia. Hal ini dapat memperbaiki sikap punggung menjadi tegak lurus dan sikap kaki pada saat pengangkatan air menjadi sikap kaki berdiri dengan tumpuan kedua kaki tegak.

\section{Evaluasi Postur Kerja untuk Posisi Memasukkan Air}

Posisi selanjutnya dari pengoperasian mesin pencuci Ubi Cilembu yaitu memasukkan air ke dalam wadah pencucian (Gambar 8), operator memasukkan air ke dalam wadah pencucian.

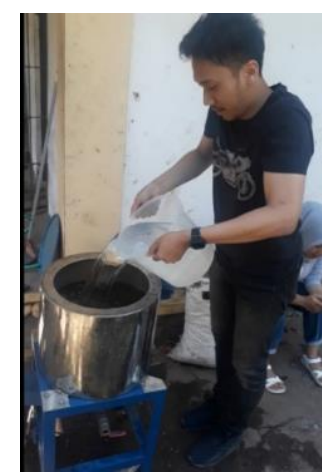

Gambar 8. Posisi Operator Memasukkan Air

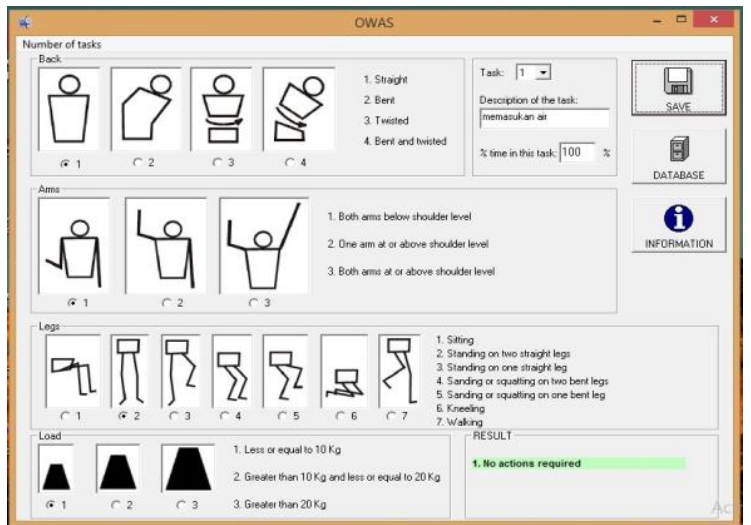

Gambar 9. Klasifikasi Sikap Kerja untuk

Posisi Operator Memasukkan Air menggunakan Software Ergofellow 2.0

Penilaian untuk postur kerja operator saat memasukkan air ke wadah pencucian yaitu 1121-1 (Gambar 9). Angka 1 pada digit pertama menunjukkan sikap punggung lurus. Angka 1 pada digit kedua menunjukkan sikap kedua lengan berada di bawah bahu. Angka 2 pada digit ketiga menunjukkan sikap kaki berdiri bertumpu pada kedua kaki lurus. Angka 1 pada digit keempat menunjukkan berat beban yang diangkat kurang atau sama dengan $10 \mathrm{~kg}$ dan angka 1 pada digit terakhir menunjukkan hasil dari analisis sikap kerja OWAS masuk ke dalam kategori 1 . Kategori ini menunjukkan bahwa pada 
sikap kerja ini tidak masalah pada sistem musculoskeletal. Jadi tidak perlu ada perbaikan.

\section{Evaluasi Postur Kerja untuk Posisi Mengangkat Ubi yang telah dicuci}

Posisi selanjutnya dari pengoperasian mesin pencuci Ubi Cilembu yaitu memasukkan air ke dalam wadah pencucian. (Gambar 10), operator memasukkan air ke dalam wadah pencucian

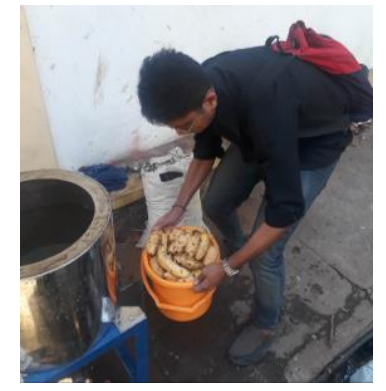

Gambar 10. Posisi Operator Mengangkat Ubi yang telah dicuci

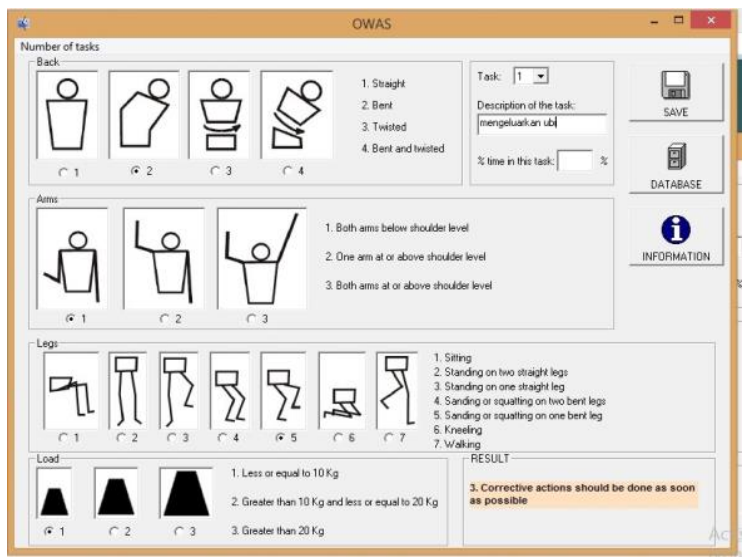

Gambar 11. Klasifikasi Sikap Kerja untuk Posisi Operator Mengangkat Ubi yang telah dicuci menggunakan Software Ergofellow 2.0

Penilaian untuk postur kerja operator saat mengangkat Ubi Cilembu basah yaitu 2151-3 (Gambar 11). Angka 2 pada digit pertama menunjukkan sikap punggung membungkuk. Angka 1 pada digit kedua menunjukkan sikap kedua lengan berada di bawah bahu. Angka 5 pada digit ketiga menunjukkan sikap kaki berdiri bertumpu pada satu kaki dengan lutut ditekuk. Angka 1 pada digit keempat menunjukkan berat beban yang diangkat kurang dari $10 \mathrm{~kg}$ dan angka 3 pada digit terakhir menunjukkan hasil dari analisis sikap kerja OWAS masuk ke dalam kategori 3. Kategori ini menunjukkan bahwa pada sikap kerja ini berbahaya bagi sistem musculoskeletal (sikap kerja mengakibatkan pengaruh ketegangan yang signifikan). Perlu perbaikan sesegera mungkin.

Dari hasil analisis postur kerja operator saat mengangkat ubi yang telah dicuci masuk ke dalam kategori 3 . Perbaikan yang dapat dilakukan salah satunya yaitu memberikan kursi kepada operator saat bekerja. Pemberian kursi ini dapat merubah sikap kerja operator pada bagian punggung dan kaki. Sikap punggung operator yang tadinya membungkuk dapat menjadi lurus, dan sikap kaki yang tadinya ditekuk dapat menjadi duduk.

\section{Evaluasi Postur Kerja untuk Posisi Menyimpan Ubi ke tempat penyimpanan}

Setelah proses pencucian, ubi cilembu dikeluarkan melalui tempat pengeluaran ubi dan turun ke wadah penampungan. (Gambar 12), operator mengangkat wadah penampungan ubi cilembu bersih. Ubi Cilembu bersih akan diangkat setelah semua ubi masuk kedalam wadah penampungan.

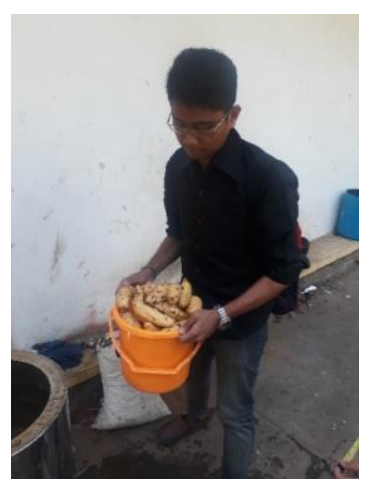

Gambar 12. Posisi Operator Menyimpan Ubi Cilembu yang telah dicuci

Penilaian untuk postur kerja operator saat akan menyimpan wadah penampungan yaitu 1121-1 (Gambar 13). Angka 1 pada digit pertama menunjukkan sikap punggung lurus. Angka 1 pada digit kedua menunjukkan sikap kedua lengan berada di bawah bahu. Angka 2 pada digit ketiga 
menunjukkan sikap kaki berdiri bertumpu pada kedua kaki lurus. Angka 1 pada digit keempat menunjukkan berat beban yang diangkat kurang dari $10 \mathrm{~kg}$ dan angka 1 pada digit terakhir menunjukkan hasil dari analisis sikap kerja OWAS masuk ke dalam kategori 1. Kategori ini menunjukkan bahwa pada sikap kerja ini tidak masalah pada sistem musculoskeletal. Jadi tidak perlu ada perbaikan.

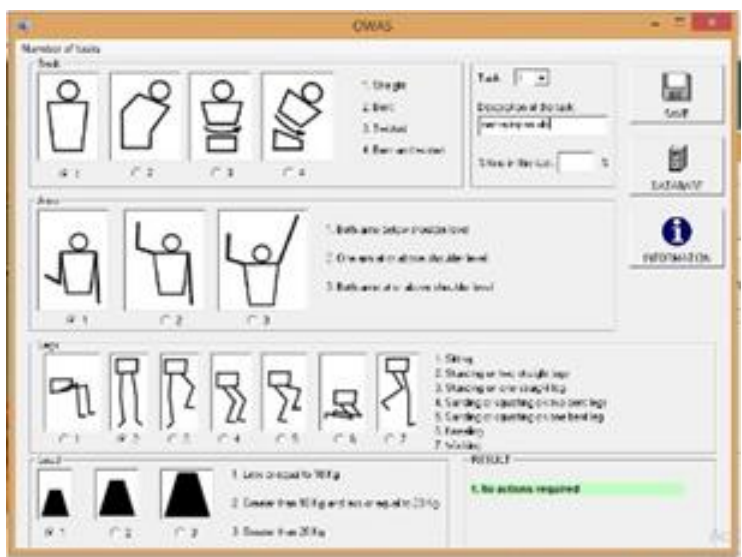

Gambar 13. Klasifikasi Sikap Kerja untuk Posisi Operator Menyimpan Ubi ke tempat penyimpanan menggunakan Software Ergofellow 2.0

\section{Analisis Metode NIOSH (National Institute of Occupational Safety and Health)}

NIOSH adalah suatu lembaga yang menangani masalah kesehatan dan keselamatan kerja di Amerika. NIOSH melakukan analisis terhadap kekuatan manusia dalam mengangkat atau memindahkan beban secara manual (Waters, et al., 1994). Persamaan yang ditetapkan oleh NIOSH adalah RWL (Recommended Weight Limit). Dari hasil perhitungan RWL, selanjutnya menghitung nilai LI (Lifting Index). Hasil dari RWL berupa rekomendasi batas beban yang dapat diangkat tanpa menimbulkan cidera, sedangkan nilai LI adalah perbandingan antara berat beban dengan nilai RWL.

Aktivitas pengangkatan beban yang dilakukan oleh operator selama mengoperasikan mesin pencuci Ubi Cilembu termasuk ke dalam pemindahan bahan secara manual. Pemindahan bahan ini terjadi pada ketiga operator. Operator pertama proses pemindahannya terjadi ketika mengangkat dan memasukkan air kedalam mesin. Lalu operator kedua proses pemindahannya terjadi ketika mengangkat dan memasukkan ubi kedalam mesin. Sedangka,n operator ketiga proses pemindahannya terjadi ketika mengangkat Ubi Cilembu di wadah penampungan dan menyimpannya ke meja penyimpanan. Maka dengan adanya pemindahan bahan secara manual ini dilakukan analisis perhitungan dengan metode NIOSH untuk mengetahui batasan beban yang dapat diangkat oleh kedua operator.

\section{Perhitungan RWL dan LI Untuk Setiap Operator}

Berdasarkan hasil perhitungan pada Tabel 1. Untuk operator pertama nilai RWL untuk tahap awal yaitu $6,323 \mathrm{~kg}$ dan nilai LI yaitu 1,51, sedangkan nilai RWL untuk tahap akhir yaitu $10,665 \mathrm{~kg}$ dan nilai LI yaitu 0,93. Dari hasil ini nilai LI yang diperoleh untuk tahap awal memiliki LI lebih dari 1. Karena nilai LI > 1, dapat disimpulkan bahwa aktivitas operator pada saat mengangkat air melebihi batas pengangkatan yang direkomendasikan, maka aktivitas tersebut mengandung resiko cidera tulang belakang. Sedangkan untuk tahap akhir memiliki nilai kurang dari 1 . Apabila nilai LI $<1$ dapat disimpulkan bahwa aktivitas operator pada saat memasukkan air ke dalam wadah pencucian, berat beban yang diangkat tidak melebihi batas pengangkatan yang direkomendasikan, maka aktivitas ini tidak mengandung resiko cidera tulang belakang.

Tabel 1. Nilai RWL dan LI untuk setiap Operator

\begin{tabular}{lllll}
\hline & $\begin{array}{l}\text { RWL } \\
\text { Awal }\end{array}$ & $\begin{array}{l}\text { LI } \\
\text { Awal }\end{array}$ & $\begin{array}{l}\text { RWL } \\
\text { Akhir }\end{array}$ & $\begin{array}{l}\text { LI } \\
\text { Akhir }\end{array}$ \\
\hline $\begin{array}{l}\text { Operator } \\
\text { pertama }\end{array}$ & 6,32 & 1,51 & 10,66 & 0,93 \\
$\begin{array}{l}\text { Operator } \\
\text { kedua }\end{array}$ & 10,08 & 0,79 & 11,11 & 0,72 \\
$\begin{array}{l}\text { Operator } \\
\text { ketiga }\end{array}$ & 11,13 & 0,71 & 14,23 & 0,56 \\
\hline
\end{tabular}


Untuk operator kedua nilai RWL untuk tahap awal yaitu $10,08 \mathrm{~kg}$ dan nilai LI yaitu 0,79 sedangkan nilai RWL untuk tahap akhir yaitu $11,11 \mathrm{~kg}$ dan nilai LI yaitu 0,72. Dari hasil ini nilai LI yang diperoleh untuk tahap awal dan tahap akhir memiliki nilai kurang dari 1 . Apabila nilai LI $<1$ dapat disimpulkan bahwa aktivitas operator pada saat memasukkan ubi kedalam wadah pencucian, berat beban yang diangkat tidak melebihi batas pengangkatan yang direkomendasikan, maka aktivitas ini tidak mengandung resiko cidera tulang belakang.

Untuk operator ketiga nilai RWL untuk tahap awal yaitu $11,13 \mathrm{~kg}$ dan nilai LI yaitu 0,71 , sedangkan nilai RWL untuk tahap akhir yaitu $14,23 \mathrm{~kg}$ dan nilai LI yaitu 0,56. Dari hasil ini nilai LI yang diperoleh untuk tahap awal dan akhir memiliki nilai kurang dari 1 . Karena nilai LI $<1$ dapat disimpulkan bahwa aktivitas operator pada saat mengangkat dan menyimpan wadah penampungan berat beban yang diangkat tidak melebihi batas pengangkatan yang direkomendasikan, maka aktivitas ini tidak mengandung resiko cidera tulang belakang.

\section{Analisis Kebisingan Mesin}

Berdasarkan data hasil pengujian kebisingan, rata-rata tingkat kebisingan yang dihasilkan pada operator $77 \mathrm{~dB}$ untuk kondisi mesin dengan beban dan 88,92 dB untuk kondisi mesin tanpa beban. Nilai tingkat kebisingan pada kondisi mesin tanpa beban lebih tinggi daripada kondisi mesin dengan beban. Salah satu faktor penyebabnya karena pada kondisi mesin dengan beban, mesin pencuci ubi ini telah terisi air, yang dapat meredam suara dari mesin pencuci ubi tersebut.

Nilai tingkat kebisingan yang dihasilkan, pada kondisi dengan beban menghasilkan nilai kebisingan di bawah 85 $\mathrm{dB}$ dan tanpa beban menghasilkan nilai kebisingan di bawah $90 \mathrm{~dB}$. Mengacu pada Peraturan Menteri Tenaga Kerja dan Transmigrasi Republik Indonesia, Nomor PER.13/MEN/X/2011 (Buchari, 2007) untuk intensitas kebisingan $90 \mathrm{~dB}$ waktu pemaparan kebisingan yang diperbolehkan yaitu selama 3 jam per hari, sedangkan untuk itensitas kebisingan di bawah $85 \mathrm{~dB}$ waktu pemaparan kebisingan yang diperbolehkan, yaitu selama 8 jam per hari. Dengan demikian, karena mesin pencuci Ubi Cilembu hanya beroperasi karena tingkat kebisingan yang dihasilkan mesin pencuci Ubi Cilembu seluruhnya di bawah $90 \mathrm{~dB}$, maka operator dapat menggunakan mesin selama 3 - 8 jam per hari.

\section{Analisis Getaran Mesin}

Berdasarkan hasil pengukuran getaran dengan menggunakan alat vibration meter diperoleh hasil untuk getaran dengan beban sebesar $11,05 \mathrm{~m} / \mathrm{s}^{2}$ dan getaran tanpa beban sebesar $21,87 \mathrm{~m} / \mathrm{s}^{2}$. Berdasarkan hasil tersebut mesin hanya diizinkan beroperasi selama 1,6 jam (ISO 10816-1: 1995). Akan tetapi, dalam penggunaan mesin pencuci ubi tersebut operator tidak harus menyentuh mesin selama mesin di operasikan. Oleh karena itu, penilaian getaran ini hanya digunakan sebagai acuan untuk operator.

\section{Analisis Ekonomi}

Analisis ekonomi dilakukan dengan menggunakan data hasil survei di lapangan, data hasil pencarian pustaka dan asumsi. Asumsi yang digunakan antara lain suku bunga bank BRI sebesar 7\% pertahun untuk kredit usaha mikro, nilai ekonomis mesin selama 5 tahun, nilai rongsok mesin $10 \%$ dari harga mesin Rp 10.810.000,-. Jasa pencucian ubi Rp 650,-/kg, jumlah hari kerja dalam satu bulan adalah 8 hari dengan jumlah jam adalah 3 jam/hari, jumlah pekerja adalah 1 (satu) orang/hari, rata-rata upah pekerja adalah Rp 50.000,-/hari, jam operasi mesin adalah $288 \mathrm{jam} / \mathrm{tahun}$ dan biaya sewa tempat usaha adalah $\mathrm{Rp}$ 500.000,-/bulan.

\section{Biaya Produksi dan Harga Pokok Produksi}

Setelah data investasi awal, data lain yang dibutuhkan untuk menganalisis 
kelayakan investasi mesin pencuci Ubi Cilembu adalah biaya pokok produksi. Untuk menentukan biaya pokok produksi dibutuhkan pula data kapasitas produksi dari mesin. Dari hasil pengujian kapasitas aktual mesin pencuci Ubi Cilembu sebesar $102,75 \mathrm{~kg} / \mathrm{jam}$.

Proses pencucian Ubi Cilembu sebaiknya dilakukan sebelum menjelang siang hari. Karena proses pencucian ini akan menghasilkan Ubi Cilembu basah yang harus segera dikeringkan. Pengeringan biasanya dilakukan dengan cara menjemur Ubi Cilembu basah di bawah sinar matahari atau bisa menggunakan kipas angin didalam ruangan. Proses pencucian dilakukan selama 2 menit, ditambah dengan waktu untuk memasukan air dan mengeluarkan ubi secara manual dari mesin pencuci ubi ini, waktu yang diperlukan sekitar kurang lebih 5 menit. Oleh karena itu, pencucian Ubi Cilembu dalam sehari kurang lebih berlangsung selama 3 jam. Maka, dalam satu hari mesin dapat menghasilkan Ubi Cilembu mentah sebanyak $308,25 \mathrm{~kg}$.

Perhitungan biaya pokok produksi dilakukan dengan menjumlahkan biaya tetap dan biaya tidak tetap. Dari hasil perhitungan, biaya tetap diperoleh sebesar Rp 9.575.014,67 dan biaya variabel yang diperoleh sebesar Rp 183,61/kg sehingga total biaya pokok produksi yaitu sebesar Rp 507,18/kg. Hasil perhitungan biaya pokok digunakan dalam metode analisis kelayakan investasi.

\section{Analisis Break Even Point}

Break Even Point atau titik impas usaha merupakan kondisi dimana besar total pengeluaran sama dengan besar total pendapatan. Perhitungan BEP menggunakan perhitungan biaya tetap pertahun, biaya tidak tetap untuk setiap $\mathrm{kg}$ Ubi Cilembu dan harga jasa pencucian ubi. Hasil perhitungan BEP dapat tersaji dalam grafik pada Gambar 14.

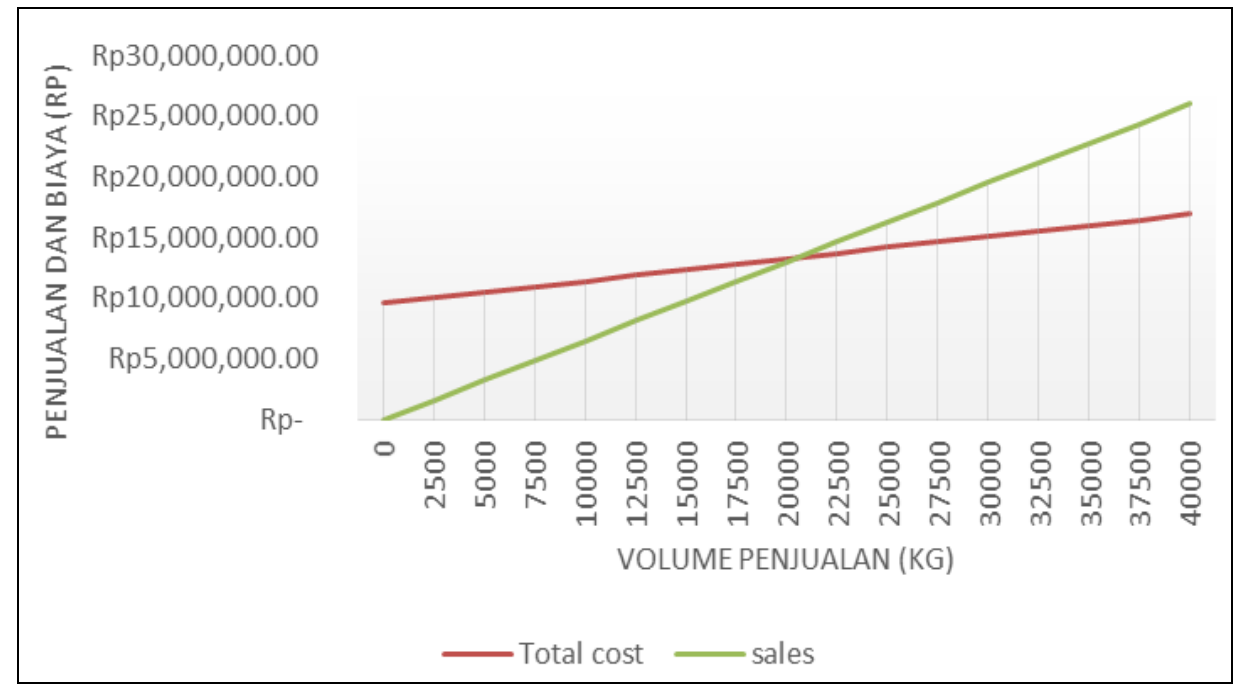

Gambar 14. Grafik Break Even Point

Harga jasa pencucian ubi berdasarkan asumsi yaitu 650,00 Rp/ kg. Dari hasil perhitungan, jasa pencucian ubi dengan menggunakan mesin pencuci Ubi Cilembu akan mencapai titik impas usaha setelah melakukan pencucian Ubi Cilembu mentah sebanyak $20.530 \mathrm{~kg} /$ tahun. Kemudian waktu yang dibutuhkan untuk mencapai titik impas usaha yaitu selama 67 hari kerja (0,7 tahun atau 8,3 bulan).

\section{Analisis Kelayakan Investasi}

Metode untuk analisis kelayakan investasi yaitu Net Present Value (NPV), Benefit Cost Ratio Analysis (BC Ratio), Internal Rate of Return (IRR) dan Pay Back Period (PBP) (Kastaman, 2004). 
Dalam analisis kelayakan investasi data yang digunakan yaitu kapasitas produksi dalam setiap tahunnya dan bunga pada tingkat suku bunga yang digunakan. Kapasitas produksi dihitung berdasarkan kapasitas produksi perhari dikalikan jumlah hari kerja dalam sebulan dan dikalikan 12 bulan. Diperoleh kapasitas produksi Ubi Cilembu pertahun sebanyak $29.592 \mathrm{~kg}$ atau $2.466 \mathrm{~kg}$ per bulan. Kemudian untuk suku bunga berdasarkan Suku Bunga Usaha Mikro Bank BRI tahun 2019 yaitu 7\%. Hasil analisis kelayakan investasi dapat dilihat pada Tabel 2 .

Tabel 2. Hasil Perbandingan Analisis Kelayakan Investasi Mesin Pencuci Ubi

\begin{tabular}{llll}
\hline Parameter & Syarat Kelayakan & Hasil Perhitungan & Ket. \\
\hline NPV & NPV $>0$ & $7.739 .007,15$ & Memenuhi \\
BC Ratio & BC Ratio $>1$ & 1,105 & Memenuhi \\
IRR & IRR $>$ MARR & $25,2 \%$ & Memenuhi \\
\hline
\end{tabular}

\section{Net Present Value (NPV)}

Metode ini didasarkan dari perhitungan aliran dana masuk (pendapatan) dan aliran dana keluar (pengeluaran) selama jangka waktu analisis dan suku bunga tertentu. Dana masuk atau pendapatan berasal dari hasil jasa pencucian Ubi Cilembu yang diasumsikan akan terjual secara keseluruhan pada setiap tahunnya. Sedangkan pengeluaran berupa biaya investasi awal untuk jasa pencucian Ubi Cilembu menggunakan mesin pencuci ubi, biaya pokok produksi yang dikeluarkan pada setiap tahunnya dan nilai akhir dari investasi yang diasumsikan sebesar $10 \%$ dari biaya awal. Jangka waktu analisis mengacu pada umur ekonomis peralatan yang diasumsikan selama 5 tahun dan suku bunga berdasarkan Suku Bunga Usaha Mikro Bank BRI tahun 2019 yaitu 7\%. Dari hasil perhitungan nilai PV pendapatan yang diperoleh sebesar Rp 81.712.188,23 dan PV pengeluaran yang diperoleh sebesar $\mathrm{Rp}$ 73.973.181,07.

Besarnya nilai NPV, yaitu Rp 7.739.007,15. Karena nilai NPV > 0, maka usaha jasa pencucian ubi menggunakan mesin pencuci ubi dinyatakan layak secara ekonomi.

\section{Benefit Cost Ratio Analysis (BC Ratio)}

BC Ratio merupakan perbandingan antara nilai sekarang dari pendapatan yang diperoleh dari kegiatan investasi dengan nilai sekarang dari pengeluaran selama investasi berlangsung dalam kurun waktu yang diasumsikan selama 5 tahun (Pujawan, 2008). Dari hasil perhitungan nilai BC Ratio adalah 1,105 . Karena nilai BC Ratio > 1, maka untuk jasa pencucian ubi menggunakan mesin pencuci ubi dinyatakan layak secara ekonomi.

\section{Internal Rate of Return (IRR)}

IRR adalah suatu nilai petunjuk yang identik dengan seberapa besar suku bunga yang dapat diberikan oleh investasi dibandingkan dengan suku bunga bank yang berlaku umum (suku bunga pasar atau Minimum Attractive Rate of Return/MARR) (Pujawan, 2008). Berdasarkan hasil perhitungan besarnya nilai IRR untuk usaha jasa pencucian ubi yaitu $25,2 \%$. Karena nilai IRR > suku bunga MARR, maka usaha jasa pencucian Ubi Cilembu menggunakan mesin pencuci ubi dinyatakan layak secara ekonomi.

\section{Pay Back Periode}

Pada metode PBP tidak digunakan perhitungan dengan menggunakan rumus bunga, akan tetapi menganalisis seberapa cepat modal atau investasi yang telah dikeluarkan dapat segera kembali. Perhitungan PBP menggunakan data pendapatan dan pengeluaran selama jangka waktu analisis yang diasumsikan selama 5 tahun (Pujawan, 2008). Berdasarkan perhitungan, investasi usaha jasa pencucian menggunakan mesin pencuci ubi dapat memberikan keuntungan pada tahun ketiga. 
Karena pada tahun ketiga keuntungan bernilai positif, sebesar Rp 1.868.959,20.

\section{KESIMPULAN DAN SARAN}

\section{Kesinpulan}

Berdasarkan hasil evaluasi postur kerja menggunakan OWAS terdapat 4 postur kerja yang termasuk ke dalam kategori 1, analisis pembebanan dengan metode NIOSH menghasilkan nilai LI $<1$ untuk semua berat beban yang diangkat operator kecuali saat operator mengangkat air, dan pengukuran kebisingan dan getaran mengizinkan mesin dioperasikan selama 3 jam -8 jam dalam satu hari. Berdasarkan hasil analisis ekonomi, BEP akan tercapai setelah mesin melakukan pencucian Ubi Cilembu sebanyak $20.530 \mathrm{~kg} / \mathrm{tahun}$. Kemudian berdasarkan analisis kelayakan investasi jasa pencucian Ubi Cilembu menggunakan mesin pencuci Ubi Cilembu didapatkan nilai NPV sebesar Rp 7,739,007.15; BC Ratio sebesar 1,105; IRR sebesar $25,2 \%$.

\section{Saran}

Adapun saran pada penelitian ini adalah perlu adanya perbaikan pada mesin dengan menambahkan batang pegangan dibagian mesin. Kedua perlu dilakukan modifikasi tutup untuk wadah pencucian mesin pencuci ubi. Perlu ditambahkan bak penampungan air yang tingginnya kurang lebih setinggi pinggul rata-rata data antropometri penduduk Indonesia. Agar sikap kerja operator dalam mengangkat air dapat membaik terutama pada bagian punggung dan kaki untuk mencegah terjadinya hal membahayakan pada sistem musculoskeletal operator.

\section{DAFTAR REFERENSI}

Buchari. (2007). Alat Pengukur Tingkat Kebisingan. Kebisingan Industri dan Hearing Conservation Program. Universitas Sumatera Utara. Badan Penerbit USU
ISO. (1995). 10816-1: Mechanical Fibration - Evaluation of Machine Vibration by Measurements on Nonrotating parts. International Organization for Standardization. Geneve. Switzerland.

Kastaman, R. (2004). Ekonomi Teknik untuk Pengembangan Kewirausahaan. Pustaka Giratuna dan ELOC - Universitas Padjadjaran. Bandung.

Nurmianto, E. (1996). Ergonomi Konsep Dasar dan Aplikasinya. Surabaya: Guna Widya.

Pujawan, I. N. (2008). Ekonomi Teknik. Guna Widya. Surabaya.

Rukmana, Rahmat. (1997). Ubi Jalar Budidaya dan Pascapanen. Yogyakarta

Suwandi. (2016). Outlook Komoditas Pertanian Tanaman Pangan Ubi Jalar. Penerbit Pusat Data dan Sistem Informasi Pertanian Kementrian Pertanian. Jakarta.

Sugandi, W., Yusuf, A., \& Widyasanti, A. (2019). Design of Cilembu Sweet Potato Cleaning Machine. International Journal of Innovative Technology and Exploring Engineering, 9(2): 5054-5058.

Suprapti, I. M. L. (2003). Teknologi Pengolahan Pangan: Tepung Ubi Jalar. Yogyakarta: Kanisius.

Waters, T. R., Putz-Anderson, V., \& Garg., A. (1994). Applications Manual for the Revised NIOSH Lifting Equation. Ohio. 